\title{
Fighting with one hand tied behind the back: political budget cycles in the West German states
}

\author{
Christina J. Schneider
}

Received: 12 September 2008 / Accepted: 5 July 2009 / Published online: 17 July 2009

(C) The Author(s) 2009. This article is published with open access at Springerlink.com

\begin{abstract}
Theories of political budget cycles have been contested because scholars find that incumbents can manipulate deficits in the pre-election period only if fiscal transparency is low. I argue that these findings do not generally rule out the possibility of fiscal electioneering. Governments may increase spending on highly visible policies. The composition of the budget serves as a second-best strategy. It increases political support without straining the budget balance. An empirical analysis of the West German states reveals alternative electoral budget strategies and ultimately point to the importance of analyzing how governments choose between alternative fiscal instruments.
\end{abstract}

Keywords Political budget cycles · German states · Deficit spending · Public goods

\section{Introduction}

An incumbent can increase her chances of re-election if she improves voter welfare before the election. She could inflate the economy to stimulate growth but the international integration of financial markets and the increase of central bank independence reduce her ability to control monetary policy, and effectively tie one of her hands behind her back. Another alternative is to pursue expansive fiscal policies, which allow the incumbent to provide more public goods or social services. With one of her hands already tied, she should have strong incentives to resort to manipulating fiscal policy. Deficit spending in the pre-election period is most often associated with a political budget cycle (PBC). ${ }^{1}$ In this scenario, incumbents

\footnotetext{
${ }^{1}$ For example. Rogoff (1990); Rogoff and Sibert (1988); Alt and Lassen (2006a, 2006b); Shi and Svensson (2006).

${ }^{2}$ Most approaches predict an increase in deficits before elections assuming that although voters dislike an increase in their individual tax contributions as well as deficits they only observe the level of taxes directly. Note, however, that cycles in fiscal policies are not necessarily limited to expenditure policies but can occur on the revenue side as well (Belke and Schneider 2006; Belke et al. 2007).
}

C.J. Schneider $(\bowtie)$

University of California, San Diego, USA

e-mail: cjschneider@ucsd.edu 
incur higher deficits in order to finance the expansion of public spending and transfer payments before elections. ${ }^{2}$ Yet, the ability to incur higher deficits is restricted by institutional constraints such as legal restrictions on the size of the deficit or membership in the European Monetary Union (EMU). Additionally, voters tend to punish leaders who are running up a budget deficit right before elections. ${ }^{3}$ This seems to tie her other hand, and as a result many scholars have concluded that in these cases electoral cycles in fiscal policies do not exist. ${ }^{4}$

I argue that this conclusion is too optimistic because the absence of deficit spending before elections does not rule out the possibility that leaders manipulate other expenditure policies for electoral gain. For instance, they can target certain groups of voters and improve their welfare while maintaining a balanced budget. Incumbents could increase spending on election-relevant items while reducing spending on other items (Drazen and Eslava 2005, 2006; Veiga and Veiga 2007). The increase in social transfers during the pre-election period is one of the most robust findings in the literature on PBCs (Franzese 2002a: 380). Yet, scholars tend to draw general conclusions from the analysis of isolated fiscal strategies such as deficit spending. My analysis of alternative pre-election strategies in the German states (Bundesländer) shows that even when deficit spending is not possible due to institutional constraints or voter preferences, political budget cycles still exist and should be expected. I find that even though incumbents on the state level decrease deficit spending and maintain a balanced budget they do increase social transfers in the pre-election period. This echoes Alt and Lassen (2006a, 2006b) and others who argue that there should be no cycles in deficit spending in countries with relatively transparent fiscal institutions. At the same time, I show that incumbents are not restricted to deficit spending but may choose alternative fiscal policy instruments - e.g., an increase in transfer payments (retaining a balanced budget) - to increase political support before an election.

The findings demonstrate that inferences from the empirical analysis of PBCs should not solely rely on the analysis of deficit spending (or any other budget item). Even if deficit spending is not feasible for institutional or political reasons, incumbents usually draw from alternative fiscal strategies to increase voter support. My paper therefore provides the empirical basis for an integrated explanation of fiscal strategies. Governments choose between alternative fiscal strategies (e.g., taxation, deficit spending, composition of expenditures, revenues) in the pre-election period. To understand these opportunistic choices, it is vital to move away from examining alternative strategies in isolation. My paper points to some of the conditions under which governments rely on one or the other instrument. For example, deficit cycles should become less likely if fiscal transparency is high. Cycles in the budget composition, however, can still exist under this condition. Future research has to specify those conditions more explicitly in order to provide a unified account of political business cycles.

\section{Can governments signal competence to the electorate?}

The incumbent's incentive to stimulate the economy before elections has attracted scholarly attention in both economics and political science and a number of highly diversified theories

\footnotetext{
${ }^{3}$ See, inter alia, Peltzman (1992); Alesina et al. (1998); Brender (2003); Buti and van der Noord (2003); Von Hagen (2003); Andrikopoulos et al. (2004); Brender and Drazen (2005); Drazen and Eslava (2005); Mink and de Haan (2005); Alt and Lassen (2006a, 2006b); Schneider (2007).

${ }^{4}$ Some examples are Persson and Tabellini (2002, 2003b), Shi and Svensson (2000, 2002, 2006), and Brender and Drazen (2005). They argue that macro-political budget cycles are restricted to weak or new democracies.
} 
exist. Initially, scholars applied the logic of the Philips curve (which constitutes an inverse relationship between inflation and unemployment) to provide an explanation for opportunistic political business cycles. In these models, the electorate votes retrospectively and governments expand monetary policies to lower unemployment before elections (Kramer 1971; Nordhaus 1975; Tufte 1975, 1978; Lindbeck 1976; Fair 1978; Hibbs 1977, 1987).

Later approaches relax the assumption that expectations about the inflation are adaptive and treat voter expectations as rational and anticipatory (Alesina 1987, 1988; Persson and Tabellini 1990). Governments cannot simply generate political business cycles because voters (who anticipate that lower unemployment before the election will lead to higher inflation after the election) adjust their behavior accordingly. Consequently, incumbents are attracted to expansionary monetary policies only if they can signal economic competence to the electorate (Persson and Tabellini 1990). ${ }^{5}$

The relevance of monetary business cycles has declined because-in the course of international economic and financial integration and the emergence of independent central banks - few governments still autonomously command monetary policy instruments. ${ }^{6}$ The incumbents' incentive to rely on political budget cycles should have therefore increased and scholars have focused on examining electoral cycles in expenditure policies.

Political budget cycles occur when governments expand the budget before elections and contract the budget in the aftermath of elections. The underlying logic of cycles in expenditure policies is similar to opportunistic monetary politics. Voters prefer governments that are able to provide more public goods for given levels of taxation and private consumption (Rogoff 1990; Shi and Svensson 2002; Alt and Lassen 2006a, 2006b). To form expectations about the government's economic performance, they observe how well governments convert revenues into public goods and vote for incumbents who are able to provide aboveaverage levels of public goods before the elections. Only competent governments can increase the provision of public goods above average levels in the period before elections without distorting the economy. Incompetent governments would therefore refrain from using stimulating policies before the elections. If fiscal operations are not observable and incumbents do not know their own competence, however, incumbents could increase the government deficit to pursue expansionary fiscal policies in the hope that the electorate attributes the increased provision of public goods to the incumbent's performance. This is what scholars dub 'hidden effort' (Persson and Tabellini 2002; Shi and Svensson 2002; Mink and de Haan 2005). Deficit spending - a policy instrument that is assumed to be hidden from the electorate-induces all governments, competent and incompetent, to generate political budget cycles. They simply increase the deficit in order to provide an above-average amount of public goods to the population. Thus, scholars concluded that cycles in expenditure policies should be more likely if governments (i) do not know their own competence level and are thus uncertain about how well they perform without distorting the budget, and (ii) cannot exploit monetary policies in the pre-election period. Scholarly work has focused on testing whether cycles in deficit spending exist because all governments increase deficits before elections in order to maximize public good provisions.

\footnotetext{
${ }^{5}$ In addition, scholars distinguish between governments acting either purely opportunistic or according to partisanship (Hibbs 1977; Alesina 1989; Cusack 1997; Midtbo 1998; Boix 2000; Grier 2008). Drazen (2000) and Franzese (2002a) provide an excellent overview.

${ }^{6}$ Obstfeld and Rogoff (1996); Lohmann (1992, 1997); Jonsson (1995); Simmons (1996); Boix (1998, 2000); Clark et al. (1998); Garrett (1998); Franzese (1999, 2003); Oatley (1999); Clark and Hallerberg (2000); Way (2000); Broz and Frieden (2001); Bernhard et al. (2002); Broz (2002); Clark (2002a).
} 
These straightforward theoretical predictions find surprisingly little support. Whereas there is some evidence for an increase in targeted expenditures before elections, ${ }^{7}$ only a few studies report opportunistically motivated deficit spending. ${ }^{8}$ Other scholars find no or a negative relationship between the pre-election period and higher spending or deficits. ${ }^{9}$ The inconclusive findings even raised doubts about the very existence of fiscal political business cycles. $^{10}$

To explain why many empirical cross-country and single-country analyses fail to find consistent evidence for deficit-induced business cycles, recent work has been concerned with the conditions under which incumbents cannot imbalance their finances to manipulate the economy before elections. For example, early work has not tested whether cycles in deficit spending are feasible instruments only if their effects are hidden from the electorate. More recent work explicitly acknowledges that voters tend to punish governments if they increase deficits before elections expecting that "a more 'competent' policymaker can expand government spending or reduce taxes and still not induce the distortion that a less 'competent' policymaker would induce" (Drazen 2000: 101). Indeed, most empirical work finds that incumbents lose political support if they visibly increase deficits before the elections. ${ }^{11}$ Incompetent governments may feign competence if the share of informed voters is relatively low and the rents of remaining in power are high (Shi and Svensson 2002). The amount of information the voter receives about the incumbent's actions (and thus the extent to which electioneering is possible) may depend, for example, on the transparency of fiscal institutions within a country. Fiscal transparency is defined as

"public openness about the structure and functions of government, fiscal policy intentions, public sector accounts, and projections. It involves ready access to reliable, comprehensive, timely, understandable, and internationally comparable information on government activities (...) so that the electorate and financial markets can accurately assess the government's financial position and the true costs and benefits of government activities, including their present and future economic and social implications" (Kopits and Craig 1998, 1).

In fiscally transparent systems, voters observe when incumbents raise deficits above average before elections. The resulting loss in public support induces incumbents to abstain from deficit spending in the pre-election period. In their seminal work on fiscal transparency and political budget cycles, Alt and Lassen (2006a: 2) conclude that "where institutions are less transparent, the cycle in fiscal balance appears, while we find no such election-related movements in higher-transparency countries." Others infer that macro-political budget cycles are restricted to democracies that are either 'weak' or 'new' because voters cannot monitor the fiscal policy process in those countries. ${ }^{12}$

Prima facie, these results suggest that fiscal transparency as well as other domestic and international constraints inhibit or at least complicate political budget cycles because governments cannot rely on deficit spending anymore. This should improve fiscal performance

\footnotetext{
${ }^{7}$ For example, Tufte (1978), Alesina and Roubini (1992); Franzese (2002b).

${ }^{8}$ Alesina et al. (1992, 1997); Shi and Svensson (2006); Persson and Tabellini (2003a).

${ }^{9}$ Brender and Drazen (2005); Jochimsen and Nuscheler (2005); De Haan and Sturm (1994); Drazen and Eslava (2005); Seitz (2000).

${ }^{10}$ See footnote 4.

${ }^{11}$ See footnote 3 .

${ }^{12}$ Akhmedov and Zhuravskaya (2004); Persson and Tabellini (2002, 2003a, 2003b); Shi and Svensson (2000, 2002, 2006); Brender and Drazen (2005).
} 
particularly in countries with high fiscal transparency. In line with Alt and Lassen, I argue that deficit spending should indeed have become less attractive in countries where fiscal transparency is high. However, fiscal transparency only ties one of the incumbent's hands behind her back. Governments may still induce electoral cycles with alternative fiscal means.

A growing body of literature provides evidence of electioneering in the composition of budget expenditures. Work in this area shows that incumbents increase spending on specific budget items such as social security while decreasing spending on others. So far, these different strategies have been largely analyzed in isolation. The fact that electoral cycles in the composition of the budget are most likely in sub-national entities (the sub-national level has greater constraints on fiscal and monetary policy tools), however, suggests that different fiscal strategies are related to one another.

Domestic and international constraints on deficit spending — such as fiscal transparencyinduce a trade off for governments. Incumbents want to increase public spending in order to signal competence to the electorate. However, they cannot raise deficits in the pre-election period to finance public good provision because deficits are either observed by voters or simply not possible. To the contrary, in fiscally transparent systems governments signal economic competence if they decrease deficit growth in the pre-election period. Voters take the reduction in the budget deficit as a signal of the incumbent's economic competence, holding all else constant. In this situation, incumbents seek for alternative strategies. Combining the two strands of the literature suggests that electoral cycles in directly manipulable policies such as transfer payments (retaining a balanced budget) are used as an alternative electoral strategy when deficit spending is not sufficient to generate political support. With this strategy, governments can spend more on specific policies even if they hold the overall budget constant because they increase spending in specific budget categories while decreasing spending on other policies.

To summarize, conclusions about the existence of an electoral cycle should not rest on an analysis of isolated fiscal strategies. Whether incumbents use one or the other strategy depends on preferences, political circumstances, and institutional constraints. I argue that $\mathrm{PBCs}$ in public good provision may exist even in countries where deficit spending is unlikely. In these cases, governments are more inclined to manipulate the composition of the budget as second-best strategy when deficit spending is not feasible. Governments will finance the higher provision of public goods by decreasing spending on election-irrelevant budget items. This allows governments to claim credit for reducing pre-election budget deficits.

The main testable implications are that if we analyze countries in which fiscal transparency is high, then (1) we should not observe any cycles in budget deficits or overall expenditures (but rather a decline in deficits), but (2) we should still be able to observe an increase in public good provision.

The German states (Bundesländer) are an example in which results for a PBC are mixed. ${ }^{13}$ These contradicting results are rather puzzling because German state governments have no monetary or tax authority. They should be particularly attracted to fiscal policies in the pre-election period. However, none of these studies explicitly addressed the fact that fiscal transparency restricts the extent to which German state governments can incur deficits before elections. According to the literature, we should expect no electoral cycles to exist in the German states. In the following, I will show empirically that this conclusion is misleading.

${ }^{13}$ For example, Galli and Rossi (2002); Jochimsen and Nuscheler (2005); Berger and Holler (2007). Other work on Germany focuses on monetary business cycles and partisan cycles (e.g., Belke 2000; Berger and Woitek 1997a, 1997b, 2001; Seitz 2000; Vaubel 1997). 


\title{
3 Empirical analysis
}

This section demonstrates the interconnectedness of electoral strategies in order to provide a basis for future theory building as to how governments choose between different fiscal strategies when maximizing their chances for reelection. I examine whether electoral cycles in fiscal policies are generally absent when incumbents are institutionally constrained and not able to increase deficits before elections. Such a task is difficult because countries have varying institutional constraints and incumbents have different fiscal instruments at their disposal. Instead of raising deficits, they could lower taxes or simply rely on monetary policy instruments to induce political support. It is thus important to hold monetary and tax policies constant. At the same time, two other conditions have to be fulfilled to create an appropriate setting for empirical analysis. On one hand, the quality of the empirical test would be greatly increased if institutional and economic factors such as fiscal transparency, economic openness, and the electoral system are held constant. On the other hand, incumbents should still have the leverage to influence fiscal policies.

A comparative analysis of the German states constitutes a good test case because it fulfills all necessary conditions. The German federal system consists of the federal level, the state level, and the local level. On the state level, there are 16 states with substantial governmental authority as determined by the German basic law (Grundgesetz). ${ }^{14}$ Art. $71 \mathrm{ff}$. play a decisive role because they assign decision-making responsibilities to the different levels of government. According to Article 71ff. state governments have important decision-making powers for many spending categories such as social security, administration, and health. These policies, together with deficit spending, are most attractive for electoral manipulation.

At the same time, state governments have no monetary authority and cannot generate electoral cycles using monetary policy instruments. They also have limited access to tax instruments through the federal council (Bundesrat). Governments must rely on expenditure policies if they aim to electioneer. For the analysis, this implies that insignificant findings between the pre-election period and deficit spending cannot be traced to the existence of monetary business cycles. This simplifies the analysis of alternative fiscal strategies and sets the basis for an analysis of fiscal strategies under institutional constraints.

The German case also holds fiscal transparency constant. My main argument is that PBCs may exist even if (or maybe because) governments cannot increase benefits for the electorate by increasing deficits. According to the literature discussed above, budget cycles are least likely in regimes with fiscally transparent institutions. The International Monetary Fund (IMF) report on fiscal transparency in Germany concludes that

\begin{abstract}
"Germany has achieved a high level of fiscal transparency. Fiscal management is carried out in accordance with a comprehensive, precise, and carefully respected body of laws and regulations. While Germany's fiscal system is highly decentralized and different levels of government enjoy significant autonomy, a common legal framework clearly assigns roles and responsibilities. Sound standards for budgeting, accounting, and reporting apply to all levels of government, multiyear budget preparation is an integral part of the process, and fiscal reporting includes contingent liabilities, guarantees, tax expenditures, and equity holdings" (IMF 2003: 1). ${ }^{15}$
\end{abstract}

\footnotetext{
${ }^{14}$ Baden-Württemberg, Bayern, Berlin, Brandenburg, Bremen, Hamburg, Hessen, MecklenburgVorpommern, Niedersachsen, Nordrhein-Westfalen, Rheinland-Pfalz, Saarland, Sachsen, Sachsen-Anhalt, Schleswig-Holstein and Thüringen.

${ }^{15}$ Alternative indices of fiscal transparency are largely congruent with this assessment (e.g. De Haan and Sturm 1994; Von Hagen 1992). Alt and Lassen assign Germany a lower grade but the authors note that their
} 
In line with this assessment, incumbents in the German states get punished at the ballots if governments increase budget deficits before elections (Schneider 2007). Thus, despite the absence of national and international restrictions for public debt incumbents should not have strong incentives to increase budget deficits before elections. Besides being necessary for my analysis, this fact also provides a tough testing ground for my argument. According to the literature, electoral cycles in transfer payments should be less likely or non-existent if they do not exist in deficit spending. Demonstrating the existence of such transfer cycles in combination with the nonexistence of deficit and spending cycles supports my argument that governments are not restricted to deficit spending but may employ alternative electioneering policies.

Finally, the comparative study of German states bears the advantage that many other institutional factors (such as the electoral system and economic openness) are constant across states and do not have to be controlled for.

\subsection{Data set and variables}

The empirical analysis uses a unique data set of public spending and deficits in the West German states from 1970 to 2003. I excluded the East German states because (incomplete) data are only available from 1992 onwards. An independent estimation for both samples is not possible because data for Berlin do not exist for East and West Germany separately. The unit of analysis is the state-year.

My theoretical argument first implies that we should not observe any cycles in budget deficits or overall expenditures in the German states (because fiscal transparency is relatively high). Rather, incumbents can signal economic competence if they visibly reduce budget deficits before the elections. However, secondly, we should still be able to observe an increase in public good provision (because governments can redistribute resources from budget items that are less relevant for elections). Despite being less attractive to governments (this strategy addresses only a targeted group of voters and implies contractions in other spending items), incumbents are attracted to target spending if nothing else because they sometimes do not have another choice. In other words, whereas the literature suggests the absence of targeted spending if the incumbent cannot increase deficits before elections my argument suggests that cycles in targeted spending should exist even if incumbents cannot increase deficits before elections.

To examine this assertion, I have to analyze a policy item that " (...) can deliver timed and clearly attributable (to incumbents) economic benefits to large numbers or specific groups of voters" (Tufte 1978; Franzese 2002a: 380). Social security expenditure fulfils these criteria and has become one of the most commonly analyzed targeted spending items in the literature on PBCs in fiscal policies. ${ }^{16}$ As an additional advantage, German state governments play an important role in the decision-making process (Art. 74 Basic Law). In sum, whereas cycles in deficit spending are unattractive for incumbents, my argument would be refuted if I did not find electoral cycles in social security spending.

My main dependent variables are therefore the annual growth of (i) the budget deficit, (ii) overall expenditures, and (iii) social security expenditures. All three variables are measured on the German state level. I took the natural logarithm of all three dependent variables.

\footnotetext{
"transparency index understates it [fiscal transparency] in France and Germany" (Alt and Lassen 2006b: 1417).

${ }^{16}$ Wright (1974); Ben-Porath (1975); Tufte (1978); Alesina (1988); Keech and Pak (1989); Blais and Nadeau (1992); Franzese (1999, 2002b, 2003); Shi and Svensson (2002); Clark (2002a, 2002b); Galli and Rossi (2002); Drazen and Eslava (2005).
} 
The growth of the budget deficit, for example, is calculated as $\Delta$ Deficit $=\ln \left(\right.$ Deficit $\left._{t}\right)-$ $\ln \left(\right.$ Deficit $\left._{t-1}\right)$. Data was provided by the Federal Statistical Office Germany.

To capture opportunistic election strategies I follow Franzese (2000) and generate an indicator for the pre-election year that takes into account the month in which the election is held. Instead of using a simple dichotomous indicator, the pre-election indicator varies between 0 and 1 . In the pre-election year the indicator is calculated as $(12-(M-1)) / 12$, whereby $M$ is the month in which the election took place. The indicator takes smaller values the later in the year the election takes place and takes the value 0 for all other years. Pre-election Year constitutes the exogenous variable of main interest in the model but it is important to control for the extent of electoral competition. ${ }^{17}$ The smaller the majority of the government coalition and the higher the odds that the government will not be re-elected, the more governments are inclined to manipulate the budget cycle. It is impossible to predict the tightness of the electoral outcome but I approximate by measuring the coalition government's vote share in the pre-election period. ${ }^{18}$ The larger the government's vote share, the less important it is to appear competent to the electorate.

Additionally, whereas governments on the state level do not have command over monetary policy instruments research suggests that the Governing Council of the German Central Bank (Bundesbank) took into account the specific interests of some larger German states at least until the Maastricht Treaty put more restrictions on its policies in 1993 (e.g., Berger and Woitek 1997b, 2001; Lohmann 1997; Vaubel 1997). This could have factually diminished incentives to generate political budget cycles before 1993. I test for this structural break by adding an interaction term between Pre-election Year and a dummy variable that takes the value 1 for all years from 1993. ${ }^{19}$

Additional control variables serve to check for the robustness of the main findings. I control for the inflation rate (country level), absolute employment in 1000 workers (state level), growth of the GDP (constant prices 1995), and for the first and second oil crisis in 1974/75 and $1978-1981$, respectively. ${ }^{20}$ I use the natural logarithms of all economic variables and also lag the economic variables on the state level in order to avoid potential problems of endogeneity or reverse causality. A dichotomous variable accounts for German unification taking the value 1 for all years after 1990 and a dummy variable captures different effects for the city states Bremen and Hamburg. It is necessary to control for the city states because (contrary to the territorial states) their budgets include the budgets of local authorities.

Many scholars argue that economic policies are not only driven by opportunistic considerations, but also by partisan ideology. Those approaches typically distinguish governments on a left-right dimension whereby left governments are assumed to be more inclined to increase deficits than conservative governments. There are four major parties in the West

\footnotetext{
${ }^{17}$ For example, Wright (1974); Tufte (1978); Schultz (1995); Price (1998); John and Ward (2001); Sutter (2003).

${ }^{18}$ Gschwend and Norpoth (2005) show that past election results are very good predictors for future electoral outcomes. For this reason, and because the variable does not constitute my main independent variable, I rely on this proxy to control for electoral competition.

${ }^{19}$ Note, the results are substantively the same if I use 1999 as break point (when monetary policy was completely handed over to the ECB). Results are available upon request.

${ }^{20}$ I also checked the robustness of my results by controlling for the lag of the natural logarithm of the size of (i) the overall population and (ii) the population which is over 65 years old. An ageing of the "Baby Boom" generation could have boosted social security spending at least in some states. The preelection effect is robust to the inclusion of such variables. However, I excluded them from the main tables because the variables are highly correlated with total employment. Results are available upon request.
} 
German party system: the conservative Christian Democratic Party (CDU), the Social Democratic Party (SPD), the Liberal Party (FDP), and the Green Party (Bündnis 90/Die Grünen). Governments typically comprise majorities run by one of the two big parties (CDU, SPD) or a coalition between CDU or SPD and one of the smaller parties. Applying the partisan hypothesis to the German case would imply that the CDU as the more conservative party is less inclined to re-distributive policies in the pre-election years than the SPD. I use a dummy variable that takes 1 if the SPD is in government and 0 if the CDU is in government. Additionally, I control for situations in which the FDP is part of the government because this would imply a right-shift of the SPD government. I further add a dichotomous variable that controls for cases in which SPD and CDU formed a grand coalition. The data set incorporates three grand coalitions: Bremen (1995-2003), Baden-Württemberg (1970-1971) and Baden-Württemberg (1992-1995). Potential partisan effects should decline in these cases. In order to check the robustness of the results I estimate the models using dummy variables for specific coalitions (SPD, CDU, SPD-FDP, CDU-FDP, SPD-Grüne). ${ }^{21}$ I also control for the partisanship of the federal government to examine whether state governments that have the same partisanship as the federal government are more likely to conduct opportunistic politics. Results for all robustness checks and descriptive statistics are available in the web appendix on the author's webpage.

\subsection{Estimation procedure}

The structure of the data demands the estimation of a time series cross-sectional model. I rely on a fixed effects model because the Hausman test suggests that alternatives (such as the random effects model or the pooled OLS model) would render the coefficients inconsistent and biased. Additionally, a fixed effects model is warranted theoretically because I am most interested in whether an incumbent manipulates expenditure if that state has an upcoming election, thus, in changes over time within states. City States does not vary over time and the fixed effects model does not allow estimating time-invariant coefficients. I therefore estimate a variant of the fixed effects estimator: the fixed effects vector decomposition (FEVD) estimator. This three-step model first estimates the constant unit effects. It then decomposes the unit effects into two parts, one of which is explained by the time-invariant variables and another unexplained part that is used in a pooled OLS estimation as a control for the unit effects (Plümper and Troeger 2007). Whereas City States would be dropped in a traditional fixed-effects model, FEVD allows me to estimate a fixed effects model which includes timeinvariant variables. Note, however, that the results of the main independent variable do not differ substantively in a pure fixed effects model (estimated without City States). Because of this and the importance of controlling for the city states which have additional budget receipts the FEVD estimator is preferable.

The FEVD estimator performs better than the alternative Hausman-Taylor (HT) procedure (Hausman and Taylor 1981). The HT procedure uses exogenous time-varying variables as instruments for the endogenous time-varying variables and exogenous time-invariant variables plus the unit means of the exogenous time-varying variables as instruments for the endogenous time-invariant variables. The HT estimator provides a solution if the instruments be uncorrelated with the errors and the unit effects but highly correlated with the endogenous

${ }^{21}$ The data set incorporates four observations in which the SPD formed a coalition government with the FDP and the Grüne. The findings are substantively the same if I code these observations into the SPD-Grüne coalition or into the SPD-FDP coalition. 
regressors. The problem is to identify such instruments because the unit effects are oftentimes unobservable. Monte Carlo analysis demonstrates that the HT performs relatively poor particularly in comparison to the FEVD model (Plümper and Troeger 2007).

The Durbin-Watson statistic of an untransformed model points to serial correlation. Whereas both the Prais-Winsten transformation and the Lagged-Dependent-Variable model (LDV) address the problem of serial correlation modeling an AR1 process seems more appropriate in this case. Nickell (1981) shows that the size of the coefficients in a LDV model cannot be interpreted directly because the coefficient of the LDV includes the first lags of all the coefficients of the other independent variables (which are correlated with the variables on the right-hand side of the equation). A LDV should also not be estimated if it was not explicitly derived from the theory because the variable will eliminate most of the variance in the dependent variable. This necessarily reduces the significance of all other independent variables. Achen (2000) demonstrates that claims that budgets are caused primarily by last year's budget are probable statistical artefacts. Including a LDV induces a substantial downward bias to the substantive coefficients (sometimes even to incorrect signs) and an artificial inflation of the LDV effect. I use the Prais-Winsten transformation because my theory does not warrant the inclusion of a LDV. ${ }^{22}$ The Durbin-Watson statistic indicates that the transformed estimator sufficiently reduces serial correlation. A standard AR(1)-process is estimated because the serial correlation of the errors is not unit specific.

Additionally, I enter a trend variable into the regression to control for dynamics over time and use panel-corrected standard errors to address heteroskedasticity of the error term across German states (Beck and Katz 1995).

\subsection{Estimation results}

Table 1 presents the empirical results for deficit spending in West German states. ${ }^{23}$ The model fits the data quite well with the $F$-test being significant for all model specifications. It is highly unlikely that the joint impact of the variables is zero.

Model 1 is the baseline model testing whether governments increase deficits in the year before the election in order to provide more public goods. The estimation results reveal that state governments abstain from raising deficits in the pre-election period. To the contrary, deficit growth declines by over $1 \%$ in the year before an election. The negative deficit growth is significant at the $10 \%$-level and robust over all model specifications (including estimations that control for the election and the post-election year). ${ }^{24}$ The finding echoes the theoretical and empirical literature discussed above. Fiscal transparency reduces the incumbent's incentive to raise deficits in the pre-election period. Incumbents seem to visibly reduce budget deficits instead. This signals economic competence when voters observe deficits.

Model 2 analyzes whether the incentives to signal competence increase with expected electoral competition. The interaction term examines the impact of the pre-election period on the deficit growth for different levels of electoral competition. Unfortunately, it is not possible to analyze the conditional effect directly. Table 2 presents the pre-election deficit growth for the 10th, 25th, 50th, 75th, and 90th sample percentiles of the government's seat share in the state parliament. The second column presents actual sample values.

\footnotetext{
${ }^{22} \mathrm{~A}$ dynamic model using the method of general moments is not appropriate because the characteristics of this estimator are unknown for samples with only few observations across time and space (e.g. Greene 2003: Chap. 13.6).

${ }^{23}$ All models are estimated with Stata 10. Replication files are available on the author's webpage.

${ }^{24}$ See Tables 6 and 7 in the web Appendix.
} 
Table 1 Estimation results: deficit spending growth

\begin{tabular}{|c|c|c|c|c|}
\hline & $\begin{array}{l}\text { Model } 1 \\
\text { (Baseline) }\end{array}$ & $\begin{array}{l}\text { Model } 2 \\
\text { (Competition) }\end{array}$ & $\begin{array}{l}\text { Model } 3 \\
\text { (Maastricht) }\end{array}$ & $\begin{array}{l}\text { Model } 4 \\
\text { (Partisan) }\end{array}$ \\
\hline Pre-election Year & $\begin{array}{l}-0.013 * \\
(0.007)\end{array}$ & $\begin{array}{l}-0.025 \\
(0.064)\end{array}$ & $\begin{array}{l}-0.019 * * \\
(0.009)\end{array}$ & $\begin{array}{l}-0.014 * \\
(0.007)\end{array}$ \\
\hline SPD in Government & & & & $\begin{array}{l}0.001 \\
(0.005)\end{array}$ \\
\hline FDP in Government & & & & $\begin{array}{l}0.007 \\
(0.014)\end{array}$ \\
\hline Grand Coalition & & & & $\begin{array}{l}-0.005^{* *} \\
(0.001)\end{array}$ \\
\hline Winning Margin*Pre-election & & $\begin{array}{l}0.000 \\
(0.001)\end{array}$ & & \\
\hline Winning Margin (Government) & & $\begin{array}{l}-0.000 \\
(0.001)\end{array}$ & & \\
\hline Maastricht & & & $\begin{array}{l}0.001 \\
(0.016)\end{array}$ & \\
\hline Maastricht*Preelection & & & $\begin{array}{l}0.015 \\
(0.015)\end{array}$ & \\
\hline Inflation (Federal) & $\begin{array}{l}0.001 \\
(0.006)\end{array}$ & $\begin{array}{l}0.001 \\
(0.006)\end{array}$ & $\begin{array}{l}0.001 \\
(0.006)\end{array}$ & $\begin{array}{l}0.001 \\
(0.006)\end{array}$ \\
\hline Employment (State) & $\begin{array}{l}0.310 * * \\
(0.086)\end{array}$ & $\begin{array}{l}0.291 * * \\
(0.089)\end{array}$ & $\begin{array}{l}0.277 * * \\
(0.087)\end{array}$ & $\begin{array}{l}0.276^{* *} \\
(0.088)\end{array}$ \\
\hline GDP Growth (State) & $\begin{array}{l}-0.380 * \\
(0.205)\end{array}$ & $\begin{array}{l}-0.381^{*} \\
(0.205)\end{array}$ & $\begin{array}{l}-0.360 * \\
(0.205)\end{array}$ & $\begin{array}{l}-0.391 * \\
(0.204)\end{array}$ \\
\hline City States & $\begin{array}{l}0.444 * * \\
(0.018)\end{array}$ & $\begin{array}{l}0.418 * * \\
(0.018)\end{array}$ & $\begin{array}{l}0.398 * * \\
(0.019)\end{array}$ & $\begin{array}{l}0.397 * * \\
(0.018)\end{array}$ \\
\hline Unification & $\begin{array}{l}-0.009 \\
(0.019)\end{array}$ & $\begin{array}{l}-0.007 \\
(0.019)\end{array}$ & & $\begin{array}{l}-0.007 \\
(0.019)\end{array}$ \\
\hline 1. Oil Crisis & $\begin{array}{l}0.023 * \\
(0.013)\end{array}$ & $\begin{array}{l}0.023 * \\
(0.013)\end{array}$ & $\begin{array}{l}0.024 * \\
(0.013)\end{array}$ & $\begin{array}{l}0.022 * \\
(0.013)\end{array}$ \\
\hline 2. Oil Crisis & $\begin{array}{l}0.002 * * \\
(0.001)\end{array}$ & $\begin{array}{l}0.002 * * \\
(0.001)\end{array}$ & $\begin{array}{l}0.003 * * \\
(0.001)\end{array}$ & $\begin{array}{l}0.002 \\
(0.005)\end{array}$ \\
\hline Trend & $\begin{array}{l}-0.005 \\
(0.006)\end{array}$ & $\begin{array}{l}-0.005 \\
(0.006)\end{array}$ & $\begin{array}{l}-0.006 \\
(0.006)\end{array}$ & $\begin{array}{l}-0.005 \\
(0.006)\end{array}$ \\
\hline Residuals & $\begin{array}{l}1.006 * * \\
(0.008)\end{array}$ & $\begin{array}{l}1.014 * * \\
(0.009)\end{array}$ & $\begin{array}{l}1.002 * * \\
(0.010)\end{array}$ & $\begin{array}{l}1.003 * * \\
(0.009)\end{array}$ \\
\hline Constant & $\begin{array}{l}-2.239 * * \\
(0.004)\end{array}$ & $\begin{array}{l}-2.069^{* *} \\
(0.004)\end{array}$ & $\begin{array}{l}-1.977 * * \\
(0.004)\end{array}$ & $\begin{array}{l}-1.977^{* *} \\
(0.004)\end{array}$ \\
\hline Conditional coefficient & & (see Table 3) & $\begin{array}{l}-0.005 \\
(0.012)\end{array}$ & \\
\hline$N$ & 280 & 280 & 280 & 280 \\
\hline Adjusted $R^{2}$ & 0.564 & 0.562 & 0.561 & 0.562 \\
\hline$F$-test & $1850 * *$ & $1370 * *$ & $1051 * *$ & $1030 * *$ \\
\hline
\end{tabular}

Two-tailed test ${ }^{*}=p<0.1,{ }^{* *} p<0.05$; robust standard errors are in parentheses 
Table 2 Conditional effects of electoral competition

\begin{tabular}{lllll} 
Sample percentile & Sample value & $\begin{array}{l}\text { Deficit } \\
\text { (Table 2) }\end{array}$ & $\begin{array}{l}\text { Spending } \\
\text { (Table 4) }\end{array}$ & $\begin{array}{l}\text { Social security } \\
\text { (Table 5) }\end{array}$ \\
\hline 10th & $47.9 \%$ & -0.014 & -0.009 & 0.016 \\
& & $(0.008)^{*}$ & $(0.008)$ & $(0.010)$ \\
25th & $49.2 \%$ & -0.014 & -0.009 & $0.015^{*}$ \\
& & $(0.008)^{*}$ & $(0.008)$ & $(0.009)$ \\
50 th & $50.9 \%$ & -0.013 & -0.009 & $0.015^{*}$ \\
& & $(0.007)^{*}$ & $(0.008)$ & $(0.009)$ \\
75 th & $53.9 \%$ & -0.013 & -0.010 & 0.014 \\
& & $(0.008)$ & $(0.009)$ & $(0.010)$ \\
90 th & $58.3 \%$ & -0.013 & -0.010 & 0.012 \\
& & $(0.012)$ & $(0.012)$ & $(0.015)$
\end{tabular}

Two-tailed test ${ }^{*}=p<0.1,{ }^{* *} p<0.05$; robust standard errors are in parentheses

The third column in Table 2 presents the conditional coefficients for deficit spending. They clearly show that governments reduce budget deficits only when the governmental coalition does not possess a comfortable majority in parliament. If incumbents have more than $53 \%$ of the seats in parliament they have no incentive to decrease deficits before the election. In this case, they do not have to worry about re-election and may thus spend more on public goods at the expense of a balanced budget (even though voters are informed about public deficits). The budget cycle does not become stronger the smaller the majority. This may be due to the coding of the independent variable which does not account for exogenous shocks to public support in the pre-election year.

Model 3 further indicates a structural break in opportunistic policies after 1993. Whereas incumbents significantly decreased budget deficits before 1993, the Maastricht Treaty which factually reduced the possibility of generating electoral cycles via the German Central Bank diminished and increased the necessity to exploit expenditure policies. Accordingly, I find that governments did not decrease deficits before elections after 1993 (see Conditional Coefficient which indicates the pre-electoral deficit after 1993). The opportunistic decrease in state deficits in the pre-election period before 1993 is only significant for CDU state governments (see Appendix, Table 10). In other words, my findings refine the existing results on deficit cycles in German states. Incumbents in the German states do not generally decrease deficits before elections. The incentives to do so was higher for CDU-led governments and decreased after incumbents could not indirectly exploit monetary policy anymore.

Finally, Model 4 finds no indication of a partisan cycle in state deficits (see, however, Table 10 for partisan effects in the pre-election period). This finding is robust to estimating the regression with specific coalition dummies or controlling for the ideology of the federal government (see Appendix, Tables 8 and 9) and in line with most work on partisan cycles in the German states (e.g., Seitz 2000; Galli and Rossi 2002; Jochimsen and Nuscheler 2005; Berger and Holler 2007). ${ }^{25}$ One possible explanation for this finding is that conservative

\footnotetext{
${ }^{25}$ Belke (2000) finds evidence of partisan cycles in employment on the federal level using co-integration techniques. Interestingly, Table 9 shows that state governments seem to incur higher debts if the federal government is led by the SPD (but not if the FDP is part of the governmental coalition). However, this does not seem conditional on the partisanship of the state government itself.
} 
bankers of the German Central Bank have counteracted any attempts to engage in expansionary policies under leftist state governments. Furthermore, grand coalitions between the SPD and the CDU significantly reduce state deficits by about $0.5 \%$. Recall, however, that we cannot draw generalizable conclusion from this finding because there only are three grand coalitions in the data set.

I now turn to the discussion of the control variables. Whereas the inflation rate does not affect public deficit growth, high economic growth significantly decreases incentives for governments to increase deficits. The two oil crises have further contributed to a significant growth of the budget deficit. The deficit growth of the city states Hamburg and Bremen is approximately $40 \%$ higher than the deficit growth of the remaining German states. These results provide some evidence for a moral hazard in small German states. In 1992 the German constitutional court justified the entitlement to a bail-out for Bremen and Saarland. This ruling could have contributed to declining incentives of certain states to limit state deficits. In fact, consistently high deficits in smaller states triggered debates about the survivability of small states in the federal system and raised demands for integrating them into larger states. Finally, German re-unification has had no significant effect on budget deficits. ${ }^{26}$

Table 3 presents the models investigating electoral cycles in overall government expenditures. German state governments do not seem to increase overall spending before elections. This is not very surprising. Since state governments cannot easily manipulate taxes or deficit spending, they cannot raise overall expenditures in the pre-election year. Similar to deficit spending, governments do not seem to significantly change their strategies under different levels of electoral competition or partisanship (see also Appendix, Tables 8 and 9). The growth rate of overall spending is approximately $20 \%$ higher in the two city states than in the other German states. Neither German unification nor most of the other economic control variables exert a robust and significant influence on the growth rate of overall spending. Nevertheless, overall spending grew significantly during the second oil crisis.

Without further analysis, the results would suggest that governments do not rely on fiscal policies to generate political support. Following my argument, however, cycles in transfer payments should still occur. Although governments cannot expand overall expenditures, they can increase social security expenditures at the expense of other budget items. This improves the welfare of voters without signalling incompetence.

Table 4 reports the results of the estimated model for social security spending and reveals very interesting insights into the electoral strategies of incumbent governments. The growth of social security expenditures increases by almost $2 \%$ in the period before an election. This significant and robust effect is a rather large. Social security represents just one of nine budget categories and on average social security spending growth is 5\% (across states and time). Model 11 which controls for the structural break in 1993 indicates that social security expenditures have been growing by almost $4 \%$ in the pre-election period after the Maastricht Treaty reduced the German Central Bank's monetary policy autonomy (see Conditional Coefficient). The effect is significant at the $5 \%$ level. In combination with the findings on the overall budget balance, I can infer that incumbents manipulate the composition of the budget when institutional constraints inhibit the use of tax instruments, monetary policies, or budget deficits. In other words, incumbents at the German state level appear to increase the provision of public goods at the expense of other budget items that might not be directly relevant or observable in the year before the election. For example, Fig. 1 presents the growth of education spending in Bremen (dashed lines mark pre-election years).

${ }^{26}$ This result is consistent with the arguments reported by Jochimsen and Nuscheler (2005). 
Table 3 Estimation results: overall spending growth

\begin{tabular}{|c|c|c|c|c|}
\hline & $\begin{array}{l}\text { Model } 5 \\
\text { (Baseline) }\end{array}$ & $\begin{array}{l}\text { Model } 6 \\
\text { (Competition) }\end{array}$ & $\begin{array}{l}\text { Model } 7 \\
\text { (Maastricht) }\end{array}$ & $\begin{array}{l}\text { Model } 8 \\
\text { (Partisan) }\end{array}$ \\
\hline Pre-election Year & $\begin{array}{l}-0.009 \\
(0.008)\end{array}$ & $\begin{array}{l}-0.001 \\
(0.064)\end{array}$ & $\begin{array}{l}0.002 \\
(0.010)\end{array}$ & $\begin{array}{l}-0.009 \\
(0.008)\end{array}$ \\
\hline Winning Margin*Preelection & & $\begin{array}{l}-0.000 \\
(0.001)\end{array}$ & & \\
\hline Winning Margin (Government) & & $\begin{array}{l}0.000 \\
(0.001)\end{array}$ & & \\
\hline Maastricht & & & $\begin{array}{l}-0.054 * * \\
(0.026)\end{array}$ & \\
\hline Maastricht*Preelection & & & $\begin{array}{l}-0.016 \\
(0.015)\end{array}$ & \\
\hline SPD in Government & & & & $\begin{array}{l}-0.003 \\
(0.005)\end{array}$ \\
\hline FDP in Government & & & & $\begin{array}{l}0.004 \\
(0.013)\end{array}$ \\
\hline Grand Coalition & & & & $\begin{array}{l}0.004 * * \\
(0.002)\end{array}$ \\
\hline Inflation (Federal) & $\begin{array}{l}0.010 \\
(0.010)\end{array}$ & $\begin{array}{l}0.009 \\
(0.010)\end{array}$ & $\begin{array}{l}0.007 \\
(0.009)\end{array}$ & $\begin{array}{l}0.010 \\
(0.010)\end{array}$ \\
\hline Employment (State) & $\begin{array}{l}0.145 \\
(0.109)\end{array}$ & $\begin{array}{l}0.176 \\
(0.125)\end{array}$ & $\begin{array}{l}0.111 \\
(0.110)\end{array}$ & $\begin{array}{l}0.149 \\
(0.122)\end{array}$ \\
\hline GDP Growth (State) & $\begin{array}{l}0.129 \\
(0.308)\end{array}$ & $\begin{array}{l}0.131 \\
(0.307)\end{array}$ & $\begin{array}{l}0.083 \\
(0.290)\end{array}$ & $\begin{array}{l}0.123 \\
(0.307)\end{array}$ \\
\hline City States & $\begin{array}{l}0.198 * * \\
(0.030)\end{array}$ & $\begin{array}{l}0.240 * * \\
(0.030)\end{array}$ & $\begin{array}{l}0.151 * * \\
(0.037)\end{array}$ & $\begin{array}{l}0.205^{* *} \\
(0.030)\end{array}$ \\
\hline Unification & $\begin{array}{l}-0.041 \\
(0.039)\end{array}$ & $\begin{array}{l}-0.043 \\
(0.038)\end{array}$ & & $\begin{array}{l}-0.040 \\
(0.039)\end{array}$ \\
\hline 1. Oil Crisis & $\begin{array}{l}0.026 \\
(0.021)\end{array}$ & $\begin{array}{l}0.025 \\
(0.021)\end{array}$ & $\begin{array}{l}0.036^{*} \\
(0.020)\end{array}$ & $\begin{array}{l}0.024 \\
(0.021)\end{array}$ \\
\hline 2. Oil Crisis & $\begin{array}{l}0.012 * * \\
(0.002)\end{array}$ & $\begin{array}{l}0.012 * * \\
(0.002)\end{array}$ & $\begin{array}{l}0.016 * * \\
(0.002)\end{array}$ & $\begin{array}{l}0.011 * \\
(0.006)\end{array}$ \\
\hline Trend & $\begin{array}{l}-0.000 \\
(0.005)\end{array}$ & $\begin{array}{l}-0.000 \\
(0.005)\end{array}$ & $\begin{array}{l}0.001 \\
(0.005)\end{array}$ & $\begin{array}{l}-0.000 \\
(0.005)\end{array}$ \\
\hline Residuals & $\begin{array}{l}0.949 * * \\
(0.008)\end{array}$ & $\begin{array}{l}0.936 * * \\
(0.007)\end{array}$ & $\begin{array}{l}0.975 * * \\
(0.011)\end{array}$ & $\begin{array}{l}0.946^{* *} \\
(0.008)\end{array}$ \\
\hline Constant & $\begin{array}{l}-1.082^{* *} \\
(0.007)\end{array}$ & $\begin{array}{l}-1.340^{* *} \\
(0.007)\end{array}$ & $\begin{array}{l}-0.832 * * \\
(0.007)\end{array}$ & $\begin{array}{l}-1.111^{* *} \\
(0.007)\end{array}$ \\
\hline Conditional Coefficient & & (see Table 3) & $\begin{array}{l}-0.015 \\
(0.011)\end{array}$ & \\
\hline$N$ & 240 & 240 & 240 & 240 \\
\hline Adjusted $R^{2}$ & 0.203 & 0.198 & 0.260 & 0.194 \\
\hline$F$-test & $1415^{* *}$ & $1735^{* *}$ & $730.3 * *$ & $1139 * *$ \\
\hline
\end{tabular}

Two-tailed test ${ }^{*}=p<0.1,{ }^{* *} p<0.05$; robust standard errors are in parentheses 
Table 4 Estimation results: social security expenditures

\begin{tabular}{|c|c|c|c|c|}
\hline & $\begin{array}{l}\text { Model } 9 \\
\text { (Baseline) }\end{array}$ & $\begin{array}{l}\text { Model } 10 \\
\text { (Competition) }\end{array}$ & $\begin{array}{l}\text { Model } 11 \\
\text { (Maastricht) }\end{array}$ & $\begin{array}{l}\text { Model } 12 \\
\text { (Partisan) }\end{array}$ \\
\hline Pre-election Year & $\begin{array}{l}0.016^{*} \\
(0.009)\end{array}$ & $\begin{array}{l}0.032 \\
(0.077)\end{array}$ & $\begin{array}{l}0.005 \\
(0.012)\end{array}$ & $\begin{array}{l}0.016^{*} \\
(0.009)\end{array}$ \\
\hline Winning Margin*Preelection & & $\begin{array}{l}-0.000 \\
(0.002)\end{array}$ & & \\
\hline Winning Margin (Government) & & $\begin{array}{l}0.002 * * \\
(0.001)\end{array}$ & & \\
\hline Maastricht & & & $\begin{array}{l}-0.089^{* *} \\
(0.028)\end{array}$ & \\
\hline Maastricht*Preelection & & & $\begin{array}{l}0.033 * \\
(0.019)\end{array}$ & \\
\hline SPD in Government & & & & $\begin{array}{l}-0.002 \\
(0.006)\end{array}$ \\
\hline FDP in Government & & & & $\begin{array}{l}0.003 \\
(0.017)\end{array}$ \\
\hline Grand Coalition & & & & $\begin{array}{l}0.026 * * \\
(0.002)\end{array}$ \\
\hline Inflation (Federal) & $\begin{array}{l}0.002 \\
(0.011)\end{array}$ & $\begin{array}{l}0.001 \\
(0.010)\end{array}$ & $\begin{array}{l}-0.002 \\
(0.010)\end{array}$ & $\begin{array}{l}0.002 \\
(0.011)\end{array}$ \\
\hline Employment (State) & $\begin{array}{l}0.642 * * \\
(0.135)\end{array}$ & $\begin{array}{l}0.751 * * \\
(0.152)\end{array}$ & $\begin{array}{l}0.506^{* *} \\
(0.131)\end{array}$ & $\begin{array}{l}0.699 * * \\
(0.153)\end{array}$ \\
\hline GDP Growth (State) & $\begin{array}{l}-0.401 \\
(0.338)\end{array}$ & $\begin{array}{l}-0.401 \\
(0.332)\end{array}$ & $\begin{array}{l}-0.460 \\
(0.324)\end{array}$ & $\begin{array}{l}-0.391 \\
(0.334)\end{array}$ \\
\hline City States & $\begin{array}{l}0.892 * * \\
(0.033)\end{array}$ & $\begin{array}{l}1.041 * * \\
(0.032)\end{array}$ & $\begin{array}{l}0.703 * * \\
(0.041)\end{array}$ & $\begin{array}{l}0.968 * * \\
(0.033)\end{array}$ \\
\hline Unification & $\begin{array}{l}-0.083 * * \\
(0.042)\end{array}$ & $\begin{array}{l}-0.090 * * \\
(0.041)\end{array}$ & & $\begin{array}{l}-0.087 * * \\
(0.042)\end{array}$ \\
\hline 1. Oil Crisis & $\begin{array}{l}0.074 * * \\
(0.023)\end{array}$ & $\begin{array}{l}0.072 * * \\
(0.022)\end{array}$ & $\begin{array}{l}0.084 * * \\
(0.022)\end{array}$ & $\begin{array}{l}0.072 * * \\
(0.023)\end{array}$ \\
\hline 2. Oil Crisis & $\begin{array}{l}0.032 * * \\
(0.002)\end{array}$ & $\begin{array}{l}0.032 * * \\
(0.002)\end{array}$ & $\begin{array}{l}0.037 * * \\
(0.002)\end{array}$ & $\begin{array}{l}0.031 * * \\
(0.008)\end{array}$ \\
\hline Trend & $\begin{array}{l}-0.001 \\
(0.006)\end{array}$ & $\begin{array}{l}-0.001 \\
(0.006)\end{array}$ & $\begin{array}{l}0.000 \\
(0.006)\end{array}$ & $\begin{array}{l}-0.001 \\
(0.006)\end{array}$ \\
\hline Residuals & $\begin{array}{l}1.025 * * \\
(0.004)\end{array}$ & $\begin{array}{l}1.015^{* *} \\
(0.003)\end{array}$ & $\begin{array}{l}1.007 * * \\
(0.005)\end{array}$ & $\begin{array}{l}1.024 * * \\
(0.004)\end{array}$ \\
\hline Constant & $\begin{array}{l}-4.921 * * \\
(0.008)\end{array}$ & $\begin{array}{l}-5.841 * * \\
(0.008)\end{array}$ & $\begin{array}{l}-3.878^{* *} \\
(0.008)\end{array}$ & $\begin{array}{l}-5.357^{* *} \\
(0.008)\end{array}$ \\
\hline Conditional coefficient & & (see Table 3) & $\begin{array}{l}0.038 * * \\
(0.014)\end{array}$ & \\
\hline$N$ & 240 & 240 & 240 & 240 \\
\hline Adjusted $R^{2}$ & 0.283 & 0.296 & 0.314 & 0.280 \\
\hline$F$-test & $8403 * *$ & $8873^{* *}$ & $4703 * *$ & $7077 * *$ \\
\hline
\end{tabular}

Two-tailed test ${ }^{*}=p<0.1,{ }^{* *} p<0.05$; robust standard errors are in parentheses 


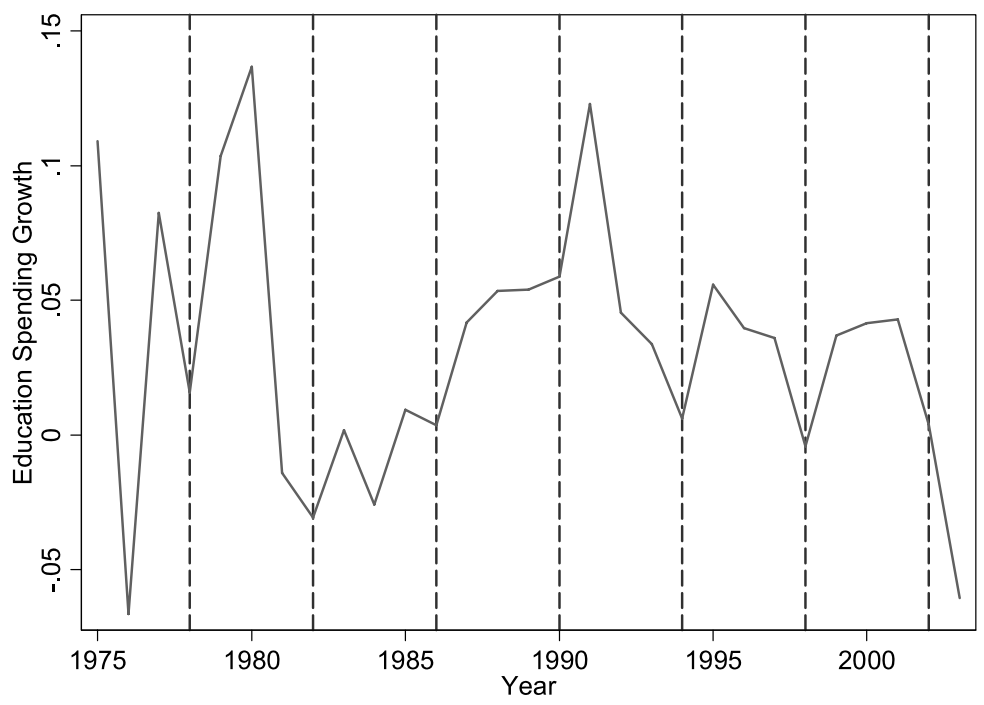

Fig. 1 Education spending growth in Bremen, 1975-2003

The graph depicts that governments in Bremen tend to decrease spending on education particularly in the pre-election year while increasing social security spending (data available upon request). However, not all states decrease pre-electoral education spending consistently. Future research has to develop theories that explain the variations across states and partisanship.

Additionally, cycles in social security expenditures exist before 1993 but only for certain states. This provides some support for the argument that the German Central Bank allowed some states to generate monetary cycles in the pre-election period and bolsters this paper's call for more in-depth analysis of substitution effects in opportunistic policies. Ultimately, Table 4 provides evidence that governments (i) by all means employ fiscal policies to stimulate the economy even if they cannot use deficit spending, and (ii) that they have different fiscal instruments at hand.

Model 10 further shows that governments are only attracted to opportunistic expenditure policies if elections are close. Ideology does not seem to affect expenditures on social security (see also Appendix, Tables 8 and 9). Only grand coalitions have higher social security expenditures. As expected, economic development reduces social security expenditures. Total employment and the two oil crises, on the other hand, significantly increase social security spending in the West German states. Hamburg and Bremen do not only spend more overall; they also have higher growth rates of social security spending than other states. Finally, German unification has led to a significant reduction of social security spending across the German states.

\section{Conclusion}

German state governments cannot exploit monetary or tax instruments to finance opportunistic policies in the pre-election period. From this point of view, it has been puzzling why they have largely abstained from extensively raising their state budget deficits albeit 
being legally able to ignore the restrictive Maastricht criteria. In fact, the public debt of the West German states has never exceeded the legal ceiling of the Maastricht criteria of $60 \%$ of the Gross Domestic Product (GDP). Across the German states, Bremen ranks first with an average fiscal deficit of approximately $34 \%$ of the GDP followed by Saarland with approximately $30 \%$. On the lower end we find the states of Southern Germany, Bayern and Baden-Württemberg, with about $10 \%$ and $12 \%$, respectively.

This paper investigated the link between political budget cycles and their empirical implications and shed some further light on fiscal strategies of incumbents who aim to get re-elected. A unified analysis of both opportunistic electoral strategies and their constraints demonstrated that governments may use alternative fiscal instruments to manipulate the economy before elections. Most importantly, the analysis provided some evidence that the conflicting results of empirical studies on deficit spending in the pre-election period should not lead to too optimistic conclusions about the government's inability to manipulate the economy before elections. Rather, those findings are largely congruent with my argument that different fiscal strategies are highly interrelated. Incumbents face a trade off. They want to increase voter welfare but are constrained by voters' fiscal conservatism. Even if cycles in monetary policies, taxation, or deficit spending are not possible due to domestic or international constraints, governments with sufficient budgetary policy autonomy may by all means exploit expenditure policies to gain voter support. The empirical analysis has indicated that although (or rather because) governments abstain from raising deficits or expenditures they manipulate the budget cycle in the pre-election period by increasing transfer payments on social security.

The paper focused on cycles in expenditure policies but governments in countries with high fiscal transparency can also generate electoral cycles if they rely on revenue policies. In line with my findings, scholars provide evidence of political partisan cycles in privatization efforts (Belke and Schneider 2006; Belke et al. 2007). This implies that governments increase privatization efforts to lower deficits and to increase economic growth (e.g., Belke et al. 2007: 20). Governments could use the expansion of revenues to generate budget cycles without further straining the budget. In other words, they could signal economic competence by increasing privatization efforts before the elections.

My findings open new interesting venues for future research. Scholars should not only analyze whether governments use a particular fiscal strategy in the electoral period but they should also theoretically and empirically investigate the conditions under which governments are likely to pursue alternative fiscal strategies. The findings presented here already pointed to different factors driving incumbent strategies. Following this argument, governments are likely to increase the voters' welfare by raising public deficits if the domestic institutional framework ensures that governments can successfully hide higher deficits from the electorate. If higher deficits are observable, however, then governments have to rely on other (potentially more costly) strategies. Voters indeed seem to award a short term improvement of their welfare before elections. As governments shy away from increasing overall expenditures in the pre-election period, the increase in social security expenditures requires a shifting of resources across budgetary items as a valuable alternative for opportunistic governments in Western democracies. Future research should investigate them in an integrated framework to shed more light on one of the most prominent and interesting features of domestic politics.

Acknowledgements I gratefully acknowledge valuable comments from two anonymous reviewers, the editors of Public Choice, Dave Armstrong, Mark Pickup, Thomas Plümper, and Vera Troeger. The project was funded by the German Research Foundation. All errors remain my responsibility. 
Open Access This article is distributed under the terms of the Creative Commons Attribution Noncommercial License which permits any noncommercial use, distribution, and reproduction in any medium, provided the original author(s) and source are credited.

\section{Appendix: Web}

Table 5 Descriptive statistics

\begin{tabular}{|c|c|c|c|c|c|}
\hline Variable & $N$ & Mean & Std. Dev. & Min & Max \\
\hline Deficit Growth & 270 & 0.07 & 0.05 & -0.12 & 0.31 \\
\hline Spending Growth & 270 & 0.03 & 0.04 & -0.12 & -0.14 \\
\hline Social Security Spending Growth & 270 & 0.05 & 0.06 & -0.13 & 0.25 \\
\hline Pre-election Year & 270 & 0.14 & 0.28 & 0 & 1 \\
\hline Inflation (Federal Level) & 270 & 0.55 & 0.74 & -2.30 & 1.44 \\
\hline Employment (State Level) & 270 & 7.53 & 0.98 & 5.90 & 9.04 \\
\hline GDP Growth Rate (State Level) & 270 & 0.02 & 0.02 & -0.05 & 0.07 \\
\hline City States & 270 & 0.20 & 0.40 & 0 & 1 \\
\hline Unification & 270 & 0.44 & 0.50 & 0 & 1 \\
\hline 1. Oil Crisis & 270 & 0.04 & 0.19 & 0 & 1 \\
\hline 2. Oil Crisis & 270 & 0.15 & 0.36 & 0 & 1 \\
\hline Winning Margin (Government) & 270 & 51.83 & 6.21 & 31.3 & 79.7 \\
\hline SPD in Government & 270 & 0.56 & 0.50 & 0 & 1 \\
\hline FDP in Government & 270 & 0.26 & 0.44 & 0 & 1 \\
\hline Grand Coalition & 270 & 0.05 & 0.21 & 0 & 1 \\
\hline Maastricht & 270 & 0.41 & 0.49 & 0 & 1 \\
\hline
\end{tabular}

Table 6 Robustness check: election year

\begin{tabular}{llll}
\hline & Deficit & Spending & Social security \\
\hline Pre-election Year & $-0.021^{* *}$ & 0.003 & -0.001 \\
Maastricht & $(0.010)$ & $(0.010)$ & $(0.012)$ \\
& 0.010 & $-0.062^{*}$ & $-0.065^{*}$ \\
Maastricht*Preelection & $(0.024)$ & $(0.034)$ & $(0.037)$ \\
Election Year & 0.016 & -0.018 & $0.038^{* *}$ \\
& $(0.015)$ & $(0.015)$ & $(0.018)$ \\
Inflation (Federal) & -0.001 & -0.000 & -0.004 \\
Employment (State) & $(0.005)$ & $(0.005)$ & $(0.006)$ \\
GDP Growth (State) & 0.002 & 0.007 & 0.001 \\
& $(0.006)$ & $(0.009)$ & $(0.010)$ \\
City States & $0.314 * *$ & 0.096 & $0.570^{* *}$ \\
Unification & $(0.086)$ & $(0.102)$ & $(0.125)$ \\
& $-0.361^{*}$ & 0.096 & -0.485 \\
& $(0.202)$ & $(0.292)$ & $(0.318)$ \\
& $0.449 * *$ & $0.131^{* *}$ & $0.792^{* *}$
\end{tabular}


Table 6 (Continued)

\begin{tabular}{llll}
\hline & Deficit & Spending & Social security \\
\hline 1. Oil Crisis & $0.024^{*}$ & $0.036^{*}$ & $0.086^{* *}$ \\
& $(0.013)$ & $(0.020)$ & $(0.022)$ \\
2. Oil Crisis & $0.003^{* *}$ & $0.016^{* *}$ & $0.037^{* *}$ \\
& $(0.001)$ & $(0.002)$ & $(0.002)$ \\
Trend & -0.005 & 0.001 & 0.001 \\
& $(0.006)$ & $(0.005)$ & $(0.006)$ \\
Residuals & $1.007^{* *}$ & $0.931 * *$ & $1.015^{* *}$ \\
Constant & $(0.008)$ & $(0.013)$ & $(0.004)$ \\
& $-2.265^{* *}$ & $-0.717 * *$ & $-4.380^{* *}$ \\
Observations & $(0.004)$ & $(0.007)$ & $(0.008)$ \\
Adjusted $R$-squared & 280 & 240 & 240 \\
$F$ & 0.562 & 0.258 & 0.323 \\
\hline
\end{tabular}

Two-tailed test ${ }^{*}=p<0.1,{ }^{* *} p<0.05$; robust standard errors are in parentheses

Table 7 Robustness check: post-election year

\begin{tabular}{|c|c|c|c|}
\hline & Deficit & Spending & Social security \\
\hline Pre-election Year & $\begin{array}{l}-0.019 * * \\
(0.009)\end{array}$ & $\begin{array}{l}0.001 \\
(0.009)\end{array}$ & $\begin{array}{l}0.000 \\
(0.011)\end{array}$ \\
\hline Maastricht & $\begin{array}{l}0.010 \\
(0.023)\end{array}$ & $\begin{array}{l}-0.063^{*} \\
(0.034)\end{array}$ & $\begin{array}{l}-0.066^{*} \\
(0.038)\end{array}$ \\
\hline Maastricht*Preelection & $\begin{array}{l}0.016 \\
(0.015)\end{array}$ & $\begin{array}{l}-0.017 \\
(0.014)\end{array}$ & $\begin{array}{l}0.038 * * \\
(0.018)\end{array}$ \\
\hline Postelection Year & $\begin{array}{l}0.006 \\
(0.005)\end{array}$ & $\begin{array}{l}-0.004 \\
(0.005)\end{array}$ & $\begin{array}{l}-0.004 \\
(0.006)\end{array}$ \\
\hline Inflation (Federal) & $\begin{array}{l}0.002 \\
(0.006)\end{array}$ & $\begin{array}{l}0.007 \\
(0.009)\end{array}$ & $\begin{array}{l}0.001 \\
(0.010)\end{array}$ \\
\hline Employment (State) & $\begin{array}{l}0.315^{* *} \\
(0.085)\end{array}$ & $\begin{array}{l}0.096 \\
(0.102)\end{array}$ & $\begin{array}{l}0.570 * * \\
(0.126)\end{array}$ \\
\hline GDP Growth (State) & $\begin{array}{l}-0.370 * \\
(0.200)\end{array}$ & $\begin{array}{l}0.101 \\
(0.292)\end{array}$ & $\begin{array}{l}-0.482 \\
(0.319)\end{array}$ \\
\hline City States & $\begin{array}{l}0.450 * * \\
(0.026)\end{array}$ & $\begin{array}{l}0.130 * * \\
(0.038)\end{array}$ & $\begin{array}{l}0.791 * * \\
(0.042)\end{array}$ \\
\hline Unification & $\begin{array}{l}-0.021 \\
(0.018)\end{array}$ & $\begin{array}{l}0.013 \\
(0.037)\end{array}$ & $\begin{array}{l}-0.041 \\
(0.040)\end{array}$ \\
\hline 1. Oil Crisis & $\begin{array}{l}0.024 * \\
(0.013)\end{array}$ & $\begin{array}{l}0.037 * \\
(0.020)\end{array}$ & $\begin{array}{l}0.084 * * \\
(0.022)\end{array}$ \\
\hline 2. Oil Crisis & $\begin{array}{l}0.003 * * \\
(0.001)\end{array}$ & $\begin{array}{l}0.016 * * \\
(0.002)\end{array}$ & $\begin{array}{l}0.036 * * \\
(0.002)\end{array}$ \\
\hline Trend & $\begin{array}{l}-0.005 \\
(0.006)\end{array}$ & $\begin{array}{l}0.001 \\
(0.005)\end{array}$ & $\begin{array}{l}0.001 \\
(0.006)\end{array}$ \\
\hline
\end{tabular}


Table 7 (Continued)

\begin{tabular}{llll}
\hline & Deficit & Spending & Social security \\
\hline Residuals & $1.009^{* *}$ & $0.924 * *$ & $1.015^{* * *}$ \\
Constant & $(0.008)$ & $(0.013)$ & $(0.004)$ \\
& $-2.275^{* *}$ & $-0.710^{* *}$ & $-4.373^{* *}$ \\
\hline Observations & $(0.004)$ & $(0.007)$ & $(0.008)$ \\
Adjusted $R$-squared & 280 & 240 & 240 \\
$F$ & 0.563 & 0.259 & 0.323 \\
\hline
\end{tabular}

Two-tailed test $*=p<0.1,{ }^{* *} p<0.05$; robust standard errors are in parentheses

Table 8 Robustness check: coalition governments

\begin{tabular}{|c|c|c|c|}
\hline & Deficit & Spending & Social security \\
\hline \multirow[t]{2}{*}{ Pre-election Year } & $-0.021 * *$ & 0.002 & 0.000 \\
\hline & $(0.009)$ & $(0.010)$ & $(0.012)$ \\
\hline \multirow[t]{2}{*}{ Maastricht } & 0.008 & $-0.064^{*}$ & $-0.069^{*}$ \\
\hline & $(0.024)$ & $(0.034)$ & $(0.036)$ \\
\hline \multirow[t]{2}{*}{ Maastricht*Preelection } & 0.018 & -0.015 & $0.040 * *$ \\
\hline & $(0.014)$ & $(0.015)$ & $(0.018)$ \\
\hline \multirow[t]{2}{*}{ SPD } & 0.001 & -0.006 & $-0.018 *$ \\
\hline & $(0.006)$ & $(0.007)$ & $(0.009)$ \\
\hline \multirow[t]{2}{*}{ SPD, FDP } & 0.012 & 0.001 & -0.001 \\
\hline & $(0.008)$ & $(0.006)$ & $(0.009)$ \\
\hline \multirow[t]{2}{*}{ CDU, FDP } & 0.012 & -0.001 & -0.015 \\
\hline & $(0.009)$ & $(0.010)$ & $(0.012)$ \\
\hline \multirow[t]{2}{*}{ SPD, Gruene } & 0.002 & -0.008 & -0.026 \\
\hline & $(0.014)$ & $(0.016)$ & $(0.019)$ \\
\hline \multirow[t]{2}{*}{ Grand Coalition } & -0.004 & -0.005 & 0.002 \\
\hline & $(0.006)$ & $(0.005)$ & $(0.006)$ \\
\hline \multirow[t]{2}{*}{ Inflation (Federal) } & 0.002 & 0.007 & 0.001 \\
\hline & $(0.006)$ & $(0.009)$ & $(0.010)$ \\
\hline \multirow[t]{2}{*}{ Employment (State) } & $0.268 * *$ & 0.103 & $0.652 * *$ \\
\hline & $(0.088)$ & $(0.113)$ & $(0.141)$ \\
\hline \multirow[t]{2}{*}{ GDP Growth (State) } & $-0.384 *$ & 0.088 & -0.484 \\
\hline & $(0.201)$ & $(0.290)$ & $(0.309)$ \\
\hline \multirow[t]{2}{*}{ City States } & $0.387 * *$ & $0.143 * *$ & $0.910 * *$ \\
\hline & $(0.027)$ & $(0.038)$ & $(0.041)$ \\
\hline \multirow[t]{2}{*}{ Unification } & -0.016 & 0.015 & -0.043 \\
\hline & $(0.019)$ & $(0.037)$ & $(0.039)$ \\
\hline \multirow[t]{2}{*}{ 1. Oil Crisis } & $0.023^{*}$ & $0.034 *$ & $0.079 * *$ \\
\hline & $(0.013)$ & $(0.020)$ & $(0.021)$ \\
\hline \multirow[t]{2}{*}{ 2. Oil Crisis } & $0.002 *$ & $0.015^{* *}$ & $0.035^{* *}$ \\
\hline & $(0.001)$ & $(0.002)$ & $(0.002)$ \\
\hline
\end{tabular}


Table 8 (Continued)

\begin{tabular}{llll}
\hline & Deficit & Spending & Social security \\
\hline Trend & -0.005 & 0.001 & 0.001 \\
& $(0.007)$ & $(0.010)$ & $(0.011)$ \\
Residuals & $1.015^{* *}$ & $0.914^{* *}$ & $1.005^{* *}$ \\
& $(0.010)$ & $(0.012)$ & $(0.004)$ \\
Constant & $-1.916^{* *}$ & $-0.766^{* *}$ & $-5.006^{* *}$ \\
& $(0.004)$ & $(0.007)$ & $(0.008)$ \\
\hline Observations & 280 & 240 & 240 \\
Adjusted $R$-squared & 0.563 & 0.247 & 0.331 \\
$F$ & $842.2^{* *}$ & $430.8^{* *}$ & $5615^{* *}$ \\
\hline
\end{tabular}

Two-tailed test ${ }^{*}=p<0.1,{ }^{* *} p<0.05$; robust standard errors are in parentheses

Table 9 Robustness check: partisanship of the federal government

\begin{tabular}{|c|c|c|c|}
\hline & Deficit & Spending & Social security \\
\hline Pre-election Year & $\begin{array}{l}-0.020^{* *} * \\
(0.009)\end{array}$ & $\begin{array}{l}-0.000 \\
(0.009)\end{array}$ & $\begin{array}{l}0.002 \\
(0.012)\end{array}$ \\
\hline Maastricht & $\begin{array}{l}-0.003 \\
(0.023)\end{array}$ & $\begin{array}{l}-0.062 * \\
(0.035)\end{array}$ & $\begin{array}{l}-0.081 * * \\
(0.038)\end{array}$ \\
\hline Maastricht*Preelection & $\begin{array}{l}0.017 \\
(0.014)\end{array}$ & $\begin{array}{l}-0.012 \\
(0.014)\end{array}$ & $\begin{array}{l}0.039 * * \\
(0.018)\end{array}$ \\
\hline SPD in Government & $\begin{array}{l}0.004 \\
(0.005)\end{array}$ & $\begin{array}{l}-0.007 \\
(0.004)\end{array}$ & $\begin{array}{l}-0.002 \\
(0.006)\end{array}$ \\
\hline FDP in Government & $\begin{array}{l}0.005 \\
(0.014)\end{array}$ & $\begin{array}{l}0.004 \\
(0.013)\end{array}$ & $\begin{array}{l}0.002 \\
(0.016)\end{array}$ \\
\hline Grand Coalition & $\begin{array}{l}-0.008 \\
(0.038)\end{array}$ & $\begin{array}{l}-0.001 \\
(0.058)\end{array}$ & $\begin{array}{l}0.020 \\
(0.063)\end{array}$ \\
\hline SPD, FDP (Federal) & $\begin{array}{l}0.015 \\
(0.016)\end{array}$ & $\begin{array}{l}0.042 * \\
(0.025)\end{array}$ & $\begin{array}{l}0.033 \\
(0.028)\end{array}$ \\
\hline SPD (Federal) & $\begin{array}{l}0.014 * * \\
(0.002)\end{array}$ & $\begin{array}{l}-0.027 * * \\
(0.003)\end{array}$ & $\begin{array}{l}0.004 \\
(0.004)\end{array}$ \\
\hline Inflation (Federal) & $\begin{array}{l}0.003 \\
(0.006)\end{array}$ & $\begin{array}{l}0.006 \\
(0.009)\end{array}$ & $\begin{array}{l}0.002 \\
(0.010)\end{array}$ \\
\hline Employment (State) & $\begin{array}{l}0.254 * * \\
(0.087)\end{array}$ & $\begin{array}{l}0.057 \\
(0.107)\end{array}$ & $\begin{array}{l}0.589 * * \\
(0.136)\end{array}$ \\
\hline GDP Growth (State) & $\begin{array}{l}-0.503^{* *} \\
(0.201)\end{array}$ & $\begin{array}{l}0.060 \\
(0.300)\end{array}$ & $\begin{array}{l}-0.643^{*} \\
(0.328)\end{array}$ \\
\hline City States & $\begin{array}{l}0.365 * * \\
(0.026)\end{array}$ & $\begin{array}{l}0.080 * * \\
(0.040)\end{array}$ & $\begin{array}{l}0.815 * * \\
(0.043)\end{array}$ \\
\hline Unification & $\begin{array}{l}-0.026 \\
(0.019)\end{array}$ & $\begin{array}{l}0.005 \\
(0.039)\end{array}$ & $\begin{array}{l}-0.051 \\
(0.042)\end{array}$ \\
\hline 1. Oil Crisis & $\begin{array}{l}0.014 \\
(0.018)\end{array}$ & $\begin{array}{l}0.042 \\
(0.029)\end{array}$ & $\begin{array}{l}0.065^{* * *} \\
(0.031)\end{array}$ \\
\hline 2. Oil Crisis & $\begin{array}{l}-0.015^{* *} * \\
(0.005)\end{array}$ & $\begin{array}{l}0.013 * * \\
(0.005)\end{array}$ & $\begin{array}{l}0.012 * * \\
(0.006)\end{array}$ \\
\hline
\end{tabular}


Table 9 (Continued)

\begin{tabular}{llll}
\hline & Deficit & Spending & Social security \\
\hline Trend & -0.004 & 0.003 & 0.002 \\
& $(0.006)$ & $(0.005)$ & $(0.006)$ \\
Residuals & $1.029 * *$ & $0.964 * *$ & $0.996^{* *}$ \\
& $(0.011)$ & $(0.022)$ & $(0.004)$ \\
Constant & $-1.833^{* *}$ & $-0.447 * *$ & $-4.551^{* *}$ \\
& $(0.004)$ & $(0.007)$ & $(0.008)$ \\
\hline Observations & 280 & 240 & 240 \\
Adjusted $R$-squared & 0.582 & 0.269 & 0.336 \\
$F$ & $1054 * *$ & $227.2 * *$ & $4170^{* *}$ \\
\hline
\end{tabular}

Two-tailed test $*=p<0.1,{ }^{* *} p<0.05$; robust standard errors are in parentheses

Table 10 Robustness check: partisanship and budget cycles

\begin{tabular}{|c|c|c|c|}
\hline & Deficit & Spending & Social security \\
\hline \multirow[t]{2}{*}{ Pre-election Year } & $-0.017 *$ & -0.001 & 0.008 \\
\hline & $(0.010)$ & $(0.010)$ & $(0.013)$ \\
\hline \multirow[t]{2}{*}{ Preelection*SPD } & -0.009 & 0.006 & -0.015 \\
\hline & $(0.017)$ & $(0.017)$ & $(0.022)$ \\
\hline \multirow[t]{2}{*}{ Maastricht } & 0.001 & $-0.054 * *$ & $-0.090 * *$ \\
\hline & $(0.016)$ & $(0.026)$ & $(0.028)$ \\
\hline \multirow[t]{2}{*}{ Maastricht*Preelection } & 0.020 & -0.019 & $0.044^{*}$ \\
\hline & $(0.018)$ & $(0.020)$ & $(0.024)$ \\
\hline \multirow[t]{2}{*}{ Inflation (Federal) } & 0.001 & 0.008 & -0.002 \\
\hline & $(0.006)$ & $(0.009)$ & $(0.010)$ \\
\hline \multirow[t]{2}{*}{ Employment (State) } & $0.245 * *$ & 0.115 & $0.539 * *$ \\
\hline & $(0.089)$ & $(0.121)$ & $(0.146)$ \\
\hline \multirow[t]{2}{*}{ GDP Growth (State) } & $-0.369 *$ & 0.070 & -0.451 \\
\hline & $(0.204)$ & $(0.291)$ & $(0.321)$ \\
\hline \multirow[t]{2}{*}{ City States } & $0.355^{* *}$ & $0.158 * *$ & $0.751 * *$ \\
\hline & $(0.019)$ & $(0.037)$ & $(0.040)$ \\
\hline \multirow[t]{2}{*}{ 1. Oil Crisis } & $0.023 *$ & $0.035^{*}$ & $0.082 * *$ \\
\hline & $(0.013)$ & $(0.020)$ & $(0.022)$ \\
\hline \multirow[t]{2}{*}{ 2. Oil Crisis } & 0.002 & $0.016 * *$ & $0.036^{* *}$ \\
\hline & $(0.006)$ & $(0.007)$ & $(0.008)$ \\
\hline \multirow[t]{2}{*}{ SPD in Government } & -0.000 & -0.003 & -0.007 \\
\hline & $(0.005)$ & $(0.005)$ & $(0.006)$ \\
\hline \multirow[t]{2}{*}{ FDP in Government } & 0.008 & 0.004 & 0.004 \\
\hline & $(0.014)$ & $(0.014)$ & $(0.017)$ \\
\hline \multirow[t]{2}{*}{ Grand Coalition } & $-0.006^{* *}$ & $0.003^{*}$ & $0.016^{* *}$ \\
\hline & $(0.001)$ & $(0.002)$ & $(0.002)$ \\
\hline \multirow[t]{2}{*}{ Trend } & -0.006 & 0.001 & -0.000 \\
\hline & $(0.006)$ & $(0.005)$ & $(0.006)$ \\
\hline
\end{tabular}


Table 10 (Continued)

\begin{tabular}{llll}
\hline & Deficit & Spending & Social security \\
\hline Residuals & $0.998^{* *}$ & $0.965^{* *}$ & $1.005^{* *}$ \\
Constant & $(0.011)$ & $(0.011)$ & $(0.004)$ \\
& $-1.730^{* *}$ & $-0.864^{* *}$ & $-4.127^{* *}$ \\
Conditional coefficient & $(0.004)$ & $(0.007)$ & $(0.008)$ \\
& -0.025 & 0.005 & -0.007 \\
Observations & $(0.016)$ & $(0.018)$ & $(0.021)$ \\
Adjusted $R$-squared & 280 & 240 & 240 \\
$F$ & 0.560 & 0.249 & 0.310 \\
\hline
\end{tabular}

Two-tailed test ${ }^{*}=p<0.1,{ }^{* *} p<0.05$; robust standard errors are in parentheses

\section{References}

Achen, C. H. (2000). Why lagged dependent variables can suppress the explanatory power of other independent variables. Polmeth Working Paper.

Akhmedov, A., \& Zhuravskaya, E. V. (2004). Opportunistic political cycles, test in a young democracy setting. Quarterly Journal of Economics, 119(4), 1301-1338.

Alesina, A. (1987). Macroeconomic policy in a two-party system as a repeated game. Quarterly Journal of Economics, 102, 651-678.

Alesina, A. (1988). Macroeconomics and politics. In O. Blanchard \& S. Fischer (Eds.), NBER macroeconomics and annual. Cambridge: MIT Press.

Alesina, A. (1989). Politics and business cycles in industrial economies. Economic Policy, 5, 55-98.

Alesina, A., \& Roubini, N. (1992). Political cycles in OECD economies. Review of Economic Studies, 59, 663-688.

Alesina, A., Cohen, G. D., \& Roubini, N. (1992). Macroeconomic policy and elections in OECD democracies. Economics and Politics, 4, 1-30.

Alesina, A., Roubini, N., \& Cohen, G. D. (1997). Political cycles and the macroeconomy. Cambridge: MIT Press.

Alesina, A., Perotti, R., \& Tavares, J. (1998). The political economy of fiscal adjustments. Brookings Papers in Economic Activity.

Alt, J. E., \& Lassen, D. (2006a). Transparency, political polarization, and political budget cycles in OECD countries. American Journal of Political Science, 50(3), 530-550.

Alt, J. E., \& Lassen, D. (2006b). Fiscal transparency, political parties, and debt in OECD countries. European Economic Review, 50, 1403-1439.

Andrikopoulos, A., Loizides, I., \& Prodromidis, K. (2004). Fiscal policy and political business cycles in the EU. European Journal of Political Economy, 20, 125-152.

Beck, N., \& Katz, J. (1995). What to do, and not to do with time series cross-section data. American Political Science Review, 89(3), 634-647.

Belke, A. (2000). Partisan political business cycles in the German labour market? Empirical tests in the light of the Lucas-critique. Public Choice, 104, 225-283.

Belke, A., \& Schneider, F. (2006). Privatization in Austria: some theoretical reasons and performance measures. In M. Köthenburger, H.-W. Sinn \& J. Whalley (Eds.), CESifo conference volume. Privatization experiences in the EU (pp. 89-115). Cambridge: MIT Press.

Belke, A., Baumgärtner, F., Setzer, R., \& Schneider, F. (2007). The different extent of privatization proceeds in EU Countries: a preliminary explanation using a Public Choice approach. Finanzarchiv, 63(2), 211243.

Ben-Porath, Y. S. (1975). The years of plenty and the years of famine-a political business cycle? Kyklos, 28, 400-403.

Berger, H., \& Holler, A. (2007). What determines fiscal policy? Evidence from German states. CESIFO Working Paper No. 2062.

Berger, H., \& Woitek, U. (1997a). Searching for political business cycles in Germany. Public Choice, 91, $179-197$.

Berger, H., \& Woitek, U. (1997b). How opportunistic are partisan German central bankers: evidence on the Vaubel hypothesis. European Journal of Political Economy, 13, 807-821. 
Berger, H., \& Woitek, U. (2001). The German political business cycle: money demand rather than monetary policy. European Journal of Political Economy, 17(3), 609-631.

Bernhard, W. T., Broz, L. J., \& Clark, W. R. (2002). The political economy of monetary institutions. Cambridge: MIT Press.

Blais, A., \& Nadeau, R. (1992). The electoral budget cycle. Public Choice, 74, 389-403.

Boix, C. (1998). Political parties, growth and equality: conservative and social democratic economic strategies in the world economy. Cambridge: Cambridge University Press.

Boix, C. (2000). Partisan governments, the international economy, and macroeconomic policies in advanced nations, 1960-1993. World Politics, 53, 38-73.

Brender, A. (2003). The effect of fiscal performance on local government election results in Israel: 19891998. Journal of Public Economics, 87, 2187-2205.

Brender, A., \& Drazen, A. (2005). Political budget cycles in new versus established democracies. Journal of Monetary Economics, 52, 1271-1295.

Broz, L. J. (2002). Political system transparency and monetary commitment regimes. International Organization, 56, 861-887.

Broz, L. J., \& Frieden, J. (2001). The political economy of international monetary relations. Annual Review of Political Science, 4, 317-343.

Buti, M., \& van der Noord, P. (2003). Discretionary fiscal policy and elections: the experience of the early years of EMU. OECD Economics Department Working Paper No. 351.

Clark, W. R. (2002a). Capitalism not globalism: capital mobility, and political control of the economy. Ann Arbor: University of Michigan Press.

Clark, W. R. (2002b). Partisan and electoral motivations and the choice of monetary institutions under fully mobile capital. International Organization, 56, 725-749.

Clark, W. R., \& Hallerberg, M. (2000). Mobile capital, domestic institutions, and electorally-induced monetary and fiscal policy. American Political Science Review, 94, 323-346.

Clark, W. R., Reichert, U. N., Lomas, S. L., \& Parker, K. L. (1998). International and domestic constraints on political business cycles in OECD economies. International Organization, 52(1), 87-120.

Cusack, T. R. (1997). Partisan politics and public finance: changes in public spending in industrialized democracies, 1955-1989. Public Choice, 91, 375-395.

De Haan, J., \& Sturm, J.-E. (1994). Political and institutional determinants of fiscal policy in the European Community. Public Choice, 80, 157-172.

Drazen, A. (2000). The political business cycle after 25 years. NBER Macroeconomics Annual, 15, $75-117$.

Drazen, A., \& Eslava, M. (2005). Electoral manipulation via expenditure composition: theory and evidence. NBER Working Paper No. W11085.

Drazen, A., \& Eslava, M. (2006). Pork barrel cycles. NBER Working Paper No. 12190.

Fair, R. C. (1978). The effect of economic events on votes for president. Review of Economics and Statistics, 60, 159-172.

Franzese, R. J. (1999). Partially independent central banks, political responsive governments, and inflation. American Journal of Political Science, 43, 681-706.

Franzese, R. J. (2000). Electoral and partisan manipulation of public debt in developed democracies, 19561990. In R. Strauch \& J. Von (Eds.), Institutions, politics and fiscal policy (pp. 61-83). Dordrecht: Kluwer Academic Press.

Franzese, R. J. (2002a). Electoral and partisan cycles in economic policies and outcomes. Annual Review of Political Science, 5, 369-421.

Franzese, R. J. (2002b). Macroeconomic policies of developed countries. Cambridge: Cambridge University Press.

Franzese, R. J. (2003). Multiple hands on the wheel: empirically modeling partial delegation and shared policy control in the open and institutionalized economy. Political Analysis, 11(4), 445-474.

Galli, E., \& Rossi, S. (2002). Political budget cycles: the case of the Western German Länder. Public Choice, 110, 283-303.

Garrett, G. (1998). Partisan politics in the global economy. Cambridge: Cambridge University Press.

Greene, W. H. (2003). Econometric analysis. Englewood Cliffs: Prentice-Hall.

Grier, K. (2008). Presidential elections and real GDP growth in the USA. Public Choice, 135(3), 337-352.

Gschwend, T., \& Norpoth, H. (2005). Prognosemodell auf dem Prüfstand: Die Bundestagswahl 2005. Politische Vierteljahresschrift, 46(4), 682-688.

Hausman, J. A., \& Taylor, W. E. (1981). Panel data and unobservable individual effects. Econometrica, 49, 1377-1398.

Hibbs, D. A. (1977). Political parties and macroeconomic policy. American Political Science Review, 23, $1467-1488$.

Hibbs, D. A. (1987). The American political economy: macroeconomics and electoral politics in the United States. Cambridge: Harvard University Press. 
International Monetary Fund (IMF) (2003). Germany. Report on observance of standards and codes-Fiscal transparency. IMF Country Report No. 03/286.

Jochimsen, B., \& Nuscheler, R. (2005). The political economy of German Länder deficits. Unpublished Working Paper.

John, P., \& Ward, H. (2001). Political manipulation in a majoritarian democracy: central government targeting of public funds to English subnational government. British Journal of Political Science, 3(3), 308-339.

Jonsson, G. (1995). Institutions and macroeconomic outcomes-the empirical evidence. Swedish Economic Policy Review, 2(1), 181-212.

Keech, W., \& Pak, K. (1989). Electoral cycles and budgetary growth in veteran's benefit programs. American Journal of Political Science, 33, 901-911.

Kopits, G., \& Craig, J. (1998). Transparency in government operations. IMF Occasional Paper No. 158.

Kramer, G. H. (1971). Short-term fluctuations in U.S. voting behavior, 1986-1964. American Political Science Review, 65, 131-143.

Lindbeck, A. (1976). Stabilization policy in open economies with endogenous politicians. American Economic Review Papers and Proceedings, 66, 1-19.

Lohmann, S. (1992). Optimal commitment in monetary policy: credibility versus flexibility. American Economic Review, 82, 273-286.

Lohmann, S. (1997). Partisan control of the money supply and decentralized appointment powers. European Journal of Political Economy, 13, 225-246.

Midtbo, T. (1998). The open politiconomy: a dynamic analysis of social democratic popularity and economic policies in Scandinavia. British Journal of Political Science, 28(1), 93-112.

Mink, M., \& de Haan, J. (2005). Has the Stability and Growth Pact impeded political budget cycles in the European Union? CESIFO Working Paper No. 1532.

Nickell, S. (1981). Biases in dynamic models with fixed effects. Econometrica, 49, 1417-1426.

Nordhaus, W. D. (1975). The political business cycle. Review of Economic Studies, 42, 169-190.

Oatley, T. H. (1999). Monetary politics. Exchange-rate cooperation in the European Union. Ann Arbor: University of Michigan Press.

Obstfeld, M., \& Rogoff, K. (1996). Foundations of international macroeconomics. Cambridge: MIT Press.

Peltzman, S. (1992). Voters as fiscal conservatives. Quarterly Journal of Economics, 107, 261-327.

Persson, T., \& Tabellini, G. (1990). Macroeconomic policy, credibility and politics. London: Harwood.

Persson, T., \& Tabellini, G. (2002). Political economics. Explaining economic policy. Cambridge: MIT Press.

Persson, T., \& Tabellini, G. (2003a). The economic effects of constitutions. Cambridge: MIT Press.

Persson, T., \& Tabellini, G. (2003b). Do electoral cycles differ across political systems? IGIER Working Paper No. 232.

Plümper, T., \& Troeger, V. E. (2007). Efficient estimation of rarely changing variables in panel data with unit fixed effects. Political Analysis, 15(2), 124-139.

Price, S. (1998). Comment on "The politics of the political business cycle". British Journal of Political Science, 28, 201-210.

Rogoff, K. (1990). Equilibrium political budget cycles. American Economic Review, 80, 21-36.

Rogoff, K., \& Sibert, A. (1988). Election and macroeconomic cycles. Review of Economic Studies, 55, 1-16.

Schneider, C. J. (2007). Politischer Opportunismus und Haushaltsdefizite in den westdeutschen Bundesländern. Politische Vierteljahresschrift, 48(2), 221-242.

Schultz, K. A. (1995). The politics of the political business cycle. British Journal of Political Science, 25(1), 79-99.

Shi, M., \& Svensson, J. (2000). Political business cycles in developed and developing countries. World Bank Working Paper.

Shi, M., \& Svensson, J. (2002). Conditional political budget cycles. Manuscript, IIES, Stockholm.

Shi, M., \& Svensson, J. (2006). Political business cycles: do they differ across countries and why? Journal of Public Economics, 90(8-9), 1367-1389.

Seitz, H. (2000). Fiscal policy, deficits, and politics of subnational government. The case of the German Länder. Public Choice, 102, 183-218.

Simmons, B. (1996). Rulers of the game: central bank independence during interwar years. International Organization, 50(3), 407-443.

Sutter, M. (2003). The political economy of fiscal policy: an experimental study on the strategic use of deficits. Public Choice, 116, 313-332.

Tufte, E. R. (1975). Determinants of the outcomes of midterm congressional elections. American Political Science Review, 69, 812-826.

Tufte, E. R. (1978). Political control of the economy. Princeton: Princeton University Press.

Vaubel, R. (1997). The bureaucratic and partisan behaviour of independent central banks: German and international evidence. European Journal of Political Economy, 13(2), 201-224. 
Veiga, L. G., \& Veiga, F. J. (2007). Political business cycles at the municipal level. Public Choice, 131, $45-65$.

Von Hagen, J. (1992). Budgeting procedures and fiscal performance in the European Community. EEC Economic Papers 96.

Von Hagen, J. (2003). Fiscal discipline and growth in Euroland. Experiences with the Stability and Growth Pact. ZEI Working Paper No. B062003.

Way, C. (2000). Central banks, partisan politics, and macroeconomic outcomes. Comparative Political Studies, 33(2), 196-224.

Wright, G. (1974). The political economy of New Deal spending: an econometric analysis. Review of Economic Statistics, 56, 30-38. 